Ilmu Pertanian (Agricultural Science)

Vol. 2 No. 1 April, 2017 : 001-008

Available online at http://journal.ugm.ac.id/jip

DOI: doi.org/10.22146/ipas.12840

\title{
In Vitro Induced Resistance of Fusarium Wilt Disease (Fusarium oxysporum f.sp. cepae) by Salicylic Acid in Shallot Cv. 'Bima Brebes'
}

\author{
Khusnul Khotimah ${ }^{1 *}$, Endang Sulistyningsih ${ }^{2}$, Arif Wibowo ${ }^{3}$ \\ ${ }^{1}$ Faculty of Agriculture, Muhadi Setiabudi University, Brebes \\ Jln. Pangeran Diponegoro Km 2 Pesantunan, Wanasari, Brebes, Jawa Tengah 52252, Indonesia \\ ${ }^{2}$ Department of Agronomy, Faculty of Agriculture, Universitas Gadjah Mada \\ Jln. Flora no. 1, Bulaksumur, Sleman, Yogyakarta 5528, Indonesia \\ ${ }^{3}$ Department of Plant Protection, Faculty of Agriculture, Universitas Gadjah Mada \\ Jln. Flora no. 1, Bulaksumur, Sleman, Yogyakarta 5528, Indonesia \\ *Corresponding email: al_khanzagreen@yahoo.com
}

Received: $6^{\text {th }}$ September 2016 ; Revised: $3^{\text {rd }}$ November 2016 ; Accepted: $24^{\text {th }}$ August 2017

\begin{abstract}
Fusarium wilt caused by Fusarium oxysporum f.sp.cepae (Foc) is one of the most important diseases of onion in Indonesia. Induced resistance was one of the effective techniques to acquire resistance to fusarium wilt in shallot. Salicylic acid (SA) had been inferred to be in endogenous signal in the systemic acquired resistance response of plants. This research aimed to study the effect of exogenously added SA to resistance in shallot callus cv. 'Bima Brebes' to fusarium wilt disease in vitro; and to determine the effective concentration of SA to induce resistance. A group of shallot callus was grown in MS medium containing varying SA concentration $(0,15,20$ and $25 \mathrm{ppm})$ in vitro for 2 weeks. Then, the callus were treated with toxin of Fusarium oxysporum, namely fusaric acid, to have observe the resistance response. In vitro selection was done twice in different fusaric acid concentration. Application of exogenous SA at all concentration did not suppres time of appearance of disease symptom yet. Toxic symptom in the callus was shown by the browning or blackening (off) of callus. Salicylic acid at concentration of $20 \mathrm{ppm}$ effectively reduced the toxic symptom up to $16.66 \%$ and supported callus regeneration better than the concentration of $15 \mathrm{ppm}$ and $25 \mathrm{ppm}$. The number of resistant callus regenerated was $66.67 \%$ at pretreatment of $20 \mathrm{ppm}$ of SA.
\end{abstract}

Keywords: Cv. ‘Bima Brebes’, Exogenous Inducer, Fusaric Acid, Regeneration of Callus

\section{INTRODUCTION}

Fusarium wilt disease is one of the most important diseases of onion in Indonesia. In several centers of onion production in Indonesia, this disease causes yield losses up to $50 \%$ (Wiyatiningsih, 2010), reduced dry weight of bulbs up to $30 \%$ at the time of storage, and as well as decreased production of onion seeds (Misra et al., 2014). Fusarium wilt caused by Fusarium oxysporum f.sp. cepae (Wiyatiningsih, 2002; Fadhilah, 2014) is a soil borne fungus which can attrack almost at all stages of plant growth (Cramer, 2000). Control of this disease is usually done by pesticides, sanitation, and crop rotation. But so far, these controls are difficult to do, especially in endemic areas (Wiyatiningsih, 2010).

Induction of resistance is one of the methods which can be used as an alternative in controlling disease caused by fungus. Induction of resistance causes physiological condition of plant defense system to be activated or stimulated natural resistance mechanisms owned by the host plant with the application of an external inducer, including physical, biological, and chemical (Agrios, 2005).

Salicylic acid (SA) is a phenolic group which plays an important role in plant defense. In the plant tissue, salicylic acid is a transduction signal molecule in plant resistance mechanisms (Malamy and Klessig, 1992; Ryals et al., 1996; Vlot et al., 2009). This can be proven by the accumulation of salicylic acid in the phloem after pathogen infection. Salicylic acid accumulation in infected plant is a signal for the next transduced to other plant parts which are not infected and will activate the genes related to resistance (pathogenesis-related genes: PRs). In addition, salicylic acid is also synthesised de novo in uninfected tissue and contribute to the systemic expression of SAR 
(Ryals et al., 1996).

Salicylic acid is one of the chemical inducer agent which is widely used in inducing resistance against various diseases. Application of salicylic acid can enhance resistance to fusarium wilt in tomatoes (Mandal et al., 2009; Ojha and Chatterjee, 2012), banana 'abaka' (Faradilla, 2011), palm dates (Dihazi et al., 2011), and against downy mildew on C20 line of maize (Hoerussalam et al., 2013).

In vitro technique is often used to select plant resistance characteristic. In vitro selection method has several advantages, including reduction of the possibility of escape, the results of in vitro selection can be repeated in a greenhouse or field, as well as pathogens used for limited testing in the laboratory (Badriah, 2001). Resistance screening in vitro can use a pure culture filtrate of fusarium fungus or fusaric acid. Fusaric acid is a compound of the result of metabolites produced by several species of Fusarium, such as Fusarium oxysporum. The use of fusaric acid in vitro selection may produce mutant cells or tissue which are insensitive to fusarium, which can lead to strains resistance to pathogen infection. This method has applied on gladiolus (Badriah, 2001), banana 'abaka' (Damayanti, 2002), vanilla (Nurcahyani et al., 2012), and muskmelon (Sujatmiko, 2013) and generated resistant plant to Fusarium spp. This experiment aimed to study the effect of exogenous SA addition to enhance plant resistance to fusarium wilt disease; and also to determine the effective concentration of SA to induce resistance in shallot cv. 'Bima Brebes' in vitro.

\section{MATERIALS AND METHODS}

The experiment was conducted in Plant Tissue Culture Laboratory, Faculty of Agriculture, UGM. Materials used were bulbs of Bima Brebes cultivar, synthetic salicylic acid $\left(\mathrm{C}_{7} \mathrm{H}_{6} \mathrm{O}_{3}\right.$ MERCK), fusaric acid-FA (SIGMA-Aldrich Co.), the MS stock based on Murashige and Skoog (1962), 2,4-D, and BAP growth hormone, and Clorox.

The treatments, concentration of salicylic acid consisted $0 \mathrm{ppm}, 15 \mathrm{ppm}, 20 \mathrm{ppm}$, and $25 \mathrm{ppm}$, were arranged in a complete random design (CRD). Each experiment unit consisted of four explant was repeated five times. The data of percentage of embryogenic callus, ability to grow of callus, percentage of symptomatic fusarium, and the percentage of callus regenerating were recorded.

The first stage began with preparing the medium.
There were three medium used, i.e. callus induction medium, pre-treatments medium by added salicylic acid, and selection medium contained fusaric acid.

Sterilization was initiated by cleaning the shallot bulbs and then soaked in a $10 \%$ clorox solution for 10 minutes. Sterile bulbs were peeled and the meristematic tissue (shoot-tip) were isolated as explants. Four explants were grown on callus induction medium (MS + $2 \mathrm{ppm} \mathrm{2,4} \mathrm{D)} \mathrm{in} \mathrm{each}$ bottle. Then the bottles were incubated in a incubation room with a constant temperature about $24^{\circ} \mathrm{C}$ until grew callus. Every 4 weeks the callus was subcultured by transferring callus on fresh callus induction medium. Embryonic callus were then isolated and subcultured in fresh induction medium for $2-3$ periods of sub-culture to be propagated.

Resistance induction was done by transferring embryonic callus to MS medium which were mixed with salicylic acid according to it appropriate concentration treatment and incubated for 2 weeks. Evaluating the response of callus resistance, the embryonic callus of each treatment unit was cultered in the selection medium I /MF1(MS + 15 ppm FA) for 4 weeks. Next, it was transferred in a selection medium II/MF2 (MS + $30 \mathrm{ppm}$ FA). Control callus was grown in MS medium. The survival callus was subcultured in a fusaric acid toxin-free medium for 1-2 months for regeneration.

\section{RESULT AND DISCUSSION}

Shoot-tip meristem explants were excised and maintained on callus growth medium for 4 weeks for generating callus. Explant began to form callus with swelling, then formed a collection of amorphous cells which then divided the continuous and compact structure. Formed white callus subsequently changed into a yellowish white and friable (easily separated). White colour in callus cells indicated that the callus cells were young and actively dividing. Yellow or yellowish white showed that the cells were grown to the phase of the active cleavage. Brown or brownish yellow showed a symptoms of aging cells or sense (Sorentina et al., 2013 ).

There were two types of callus formed on callus induction medium, i.e. embryonic and non embryonic callus. Embryonic callus had a potential to grow and develop into plantlet. Embryonic callus had characteristics of yellowish white in colour, shiny, and friable (easily separated form the fragment). Meanwhile, the nonembryonic callus had a brownish-yellow, somewhat pale, watery, and subtle (Peterson and Smith, 1991). In this study, the embryonic callus had 


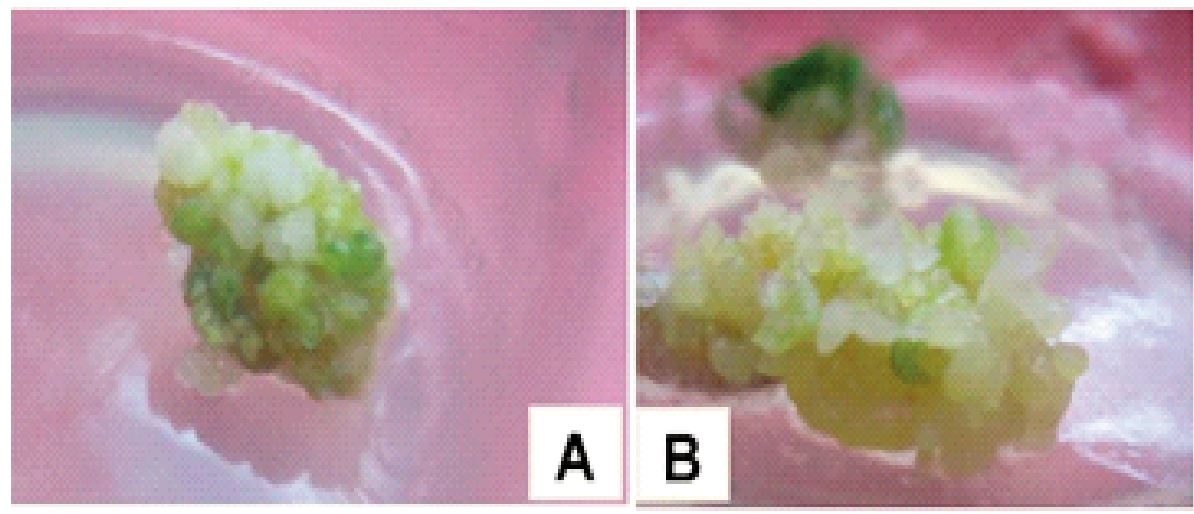

Figure 1. Structure and form callus produced on callus induction medium (A). non embryonic callus; (B). embryonic callus.
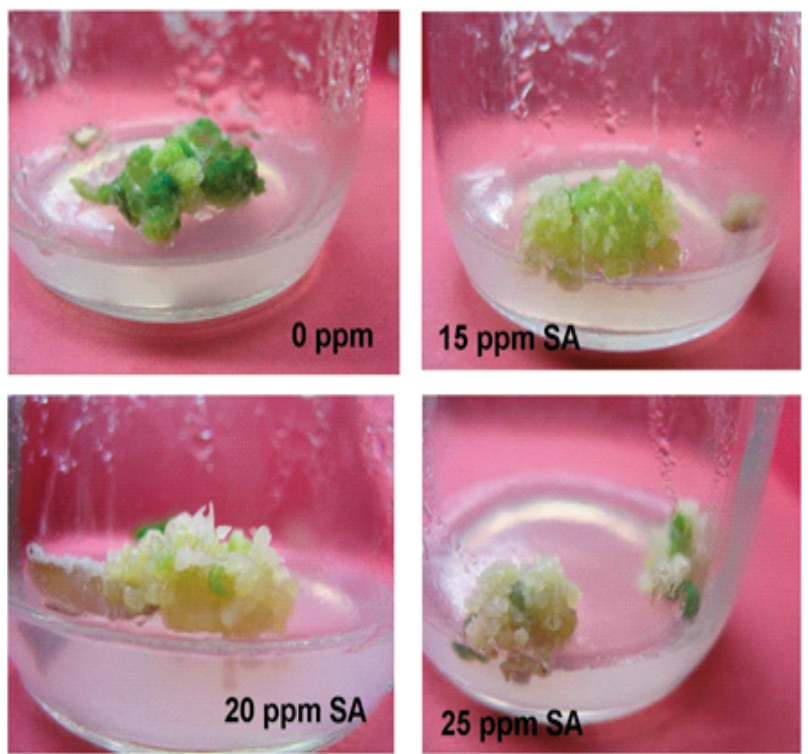

Figure 2. Performance callus of inducted resistance-result by salicylic acid at 4 weeks after subculture.

friable structure, yellowish white to greenish in colour, and globular formed. Meanwhile the non embryonic callus were white with compact structure (subtle), and not watery (Figure 1). The percentage of embryonic callus formed was $80 \%$.

Induction for generating induced resistance was carried out for 2 weeks on solid medium containing salicylic acid. This expectation of the salicylic acid application, the callus could optimally absorbe SA. Callus was subcultured in salicylic acid-free medium before treated with fusaric acid. According to Agrios

Table 1. Percentage of live callus after induction treatment by salicylic acid

\begin{tabular}{cccc}
\hline \multirow{2}{*}{$\begin{array}{c}\text { Concentration } \\
\text { of SA }\end{array}$} & \multicolumn{3}{c}{ Average of live callus group (\%) } \\
\cline { 2 - 4 } & IR & SC I & SC II \\
\hline 0 ppm & 100 & 100 & 100 \\
$15 \mathrm{ppm}$ & 100 & 100 & 100 \\
$20 \mathrm{ppm}$ & 100 & 100 & 100 \\
$25 \mathrm{ppm}$ & 100 & 100 & 100 \\
\hline
\end{tabular}

Remarks: IR = induced resistance by $\mathrm{SA}, \mathrm{SC}=$ subculture.
(2005), induced resistance would succeed if there was a period of time between inducing treatments and challenging treatments. The time period was required by plant to synthesise chemicals and move systemically to the plant tissue.

The observation of a callus showed that inducing resistance with salicylic acid at all concentrations did not cause the death of callus (Table 1). The callus was still survive after callus exposed in the salicylic acid. Treatments of salicylic acid at a concentration of 15 ppm, $20 \mathrm{ppm}$, and $25 \mathrm{ppm}$ were not toxic to embryonic callus. Callus could even grow well after inducing with salicylic acid. This was demonstrated by the percentage of surviving callus up to $100 \%$ in subculture I and II. This finding was in according to result in Abo-Elyousr et al. (2009) experiment, salicylic acid was a non-toxic compound and could be applied to plants for controlling pathogen infection.

Callus treated by SA showed a better performance compared with the callus in control treatment. It implied a live callus had induced resistance. Salicylic 


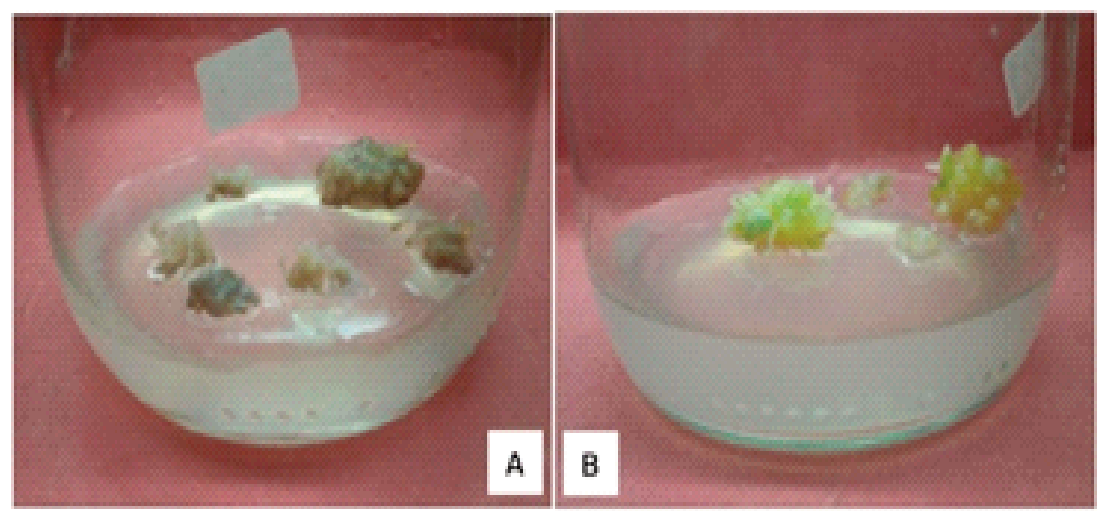

Figure 3. Condition of callus at 4 weeks after tested resistance in medium containing fusaric acid (A). toxic symptom (browning/blackening); (B). healthy callus.

Table 2. The incubation period of disease symptoms on callus induced results by SA

\begin{tabular}{cccc}
\hline \multirow{2}{*}{$\begin{array}{c}\text { Concentration of } \\
\text { SA }\end{array}$} & \multicolumn{2}{c}{$\begin{array}{c}\text { Incubation period of disease symptoms on selection } \\
\text { medium containing fusaric acid (day after treated) }\end{array}$} \\
\cline { 2 - 4 } & $0 \mathrm{ppm}$ & $15 \mathrm{ppm}^{\mathrm{a}}$ & $30 \mathrm{ppm}$ \\
\hline $0 \mathrm{ppm}$ & 0 & $21 \pm 0.00^{\mathrm{ns}}$ & $16 \pm 13.86^{\mathrm{ns}}$ \\
$15 \mathrm{ppm}$ & 0 & $21 \pm 0.00^{\mathrm{ns}}$ & $15 \pm 0.00^{\mathrm{ns}}$ \\
$20 \mathrm{ppm}$ & 0 & $18 \pm 5.19^{\mathrm{ns}}$ & $15 \pm 0.00^{\mathrm{ns}}$ \\
$25 \mathrm{ppm}$ & 0 & $18 \pm 5.19^{\mathrm{ns}}$ & $15 \pm 0.00^{\mathrm{ns}}$ \\
\hline
\end{tabular}

Remarks: Number followed by the same letter in the same column show no significant based on duncan test at $\alpha=5 \%, \mathrm{a}=$ value of deviation standard.

Table 3. Response callus of induced resistance-result on selection media containing fusaric acid 4 weeks after challenging

\begin{tabular}{cccc}
\hline \multirow{2}{*}{$\begin{array}{c}\text { Concentration of } \\
\text { SA }\end{array}$} & \multicolumn{3}{c}{$\begin{array}{c}\text { Average of number of toxic symptomatic callus on } \\
\text { selection medium containing fusaric acid (\%) }\end{array}$} \\
\cline { 2 - 4 } & $0 \mathrm{ppm}$ & $15 \mathrm{ppm}^{\mathrm{a}}$ & $30 \mathrm{ppm}$ \\
\hline $0 \mathrm{ppm}$ & 0 & $93.33 \pm 11.55^{\mathrm{ns}}$ & $83.33 \pm 23.57^{\mathrm{ns}}$ \\
$15 \mathrm{ppm}$ & 0 & $87.50 \pm 12.50^{\mathrm{ns}}$ & $100.00 \pm 0.00^{\mathrm{ns}}$ \\
$20 \mathrm{ppm}$ & 0 & $57.41 \pm 8.49^{\mathrm{ns}}$ & $66.67 \pm 57.74^{\mathrm{ns}}$ \\
$25 \mathrm{ppm}$ & - & $47.38 \pm 19.43^{\mathrm{ns}}$ & $80.00 \pm 28.28^{\mathrm{ns}}$ \\
\hline
\end{tabular}

Remarks: Number followed by the same letter in the same column show no significant based on duncan test at $\alpha=5 \%, \mathrm{a}=$ value of deviation standard.

acid thought to influence the growth and morphogenesis of callus. A callus group with SA induced resistance was yellowish white to greenish coloured in average, with friable to intermediates structure, and globular form. Meanwhile, the callus group without salicylic acid treatment had cream-coloured, compact structure, and did not progress (Figure 2).

Fusaric acid could be used as a component of selection at certain concentrations. This method had been successfully used for screening resistance to fusarium wilt disease at gladiolus (Badriah, 2001), banana 'Abaka' (Damayanti, 2002), vanilla (Nurcahyani et al., 2012), and melon (Sujatmiko, 2013). According to Arai and Takeuchi (1993), there was a positive correlation between planlet resistance to Fusarium and fusaric acid. The resistance screening was conducted twice in a selection medium containing different concentration of fusaric acid (15 ppm, and $30 \mathrm{ppm})$.

Observations of toxic symptoms were done visually after the testing of resistance by fusaric acid and incubated for 4 weeks at the intervals of 3 days. The symptoms indicated pain callus was browning or blacking (dead), that was similar with Gauman (1957) report on tomato plants. Stems of tomato plants by fusaric acid asymptomatic vascular vessels were damaged and wrinkled gray light green. In addition, fusaric acid also caused a chlorosis on the leaves of tomato. In this study, the symptoms began by colour change of callus from pale white to brownish or gray (off), and the next callus shriveled and did not develop (Figure 3).

Resistance screening in vitro was done by transferring the embryonic callus in media containing various 


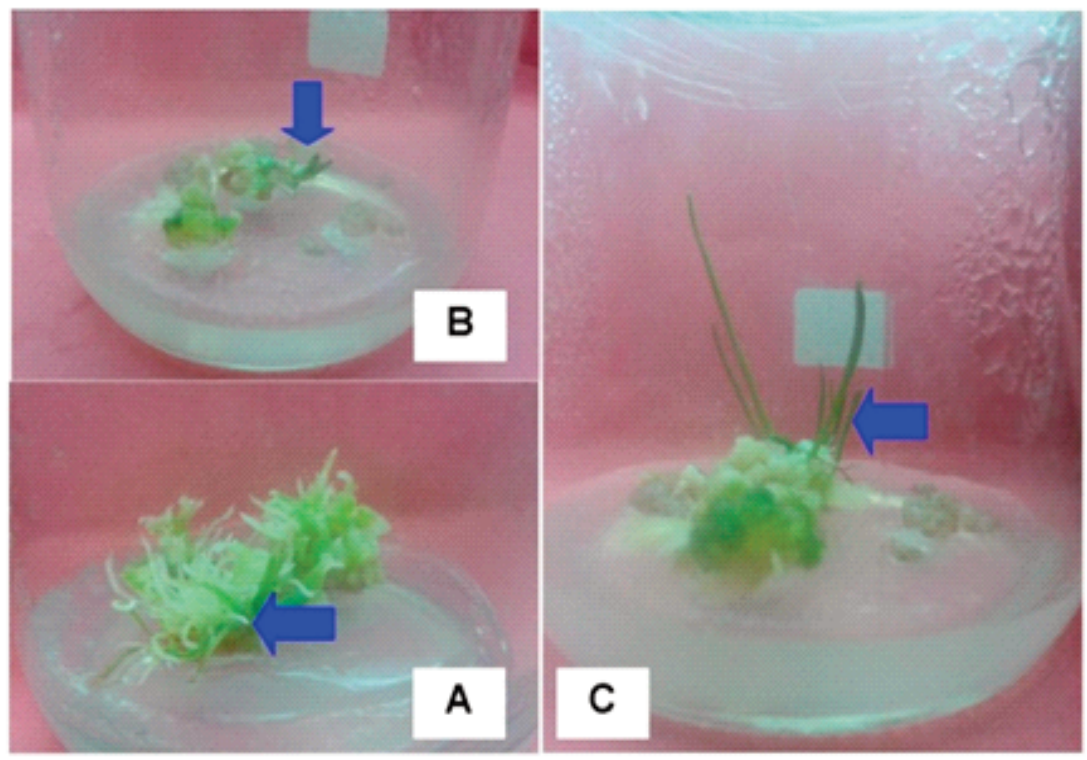

Figure 4. Performance of resistant calluswhich could regenerate into roots and shoots at 4 weeks after subculture in aregeneration medium (showed by the blue arrows). (A). cotyledons; (B). shoot candidate; (C). leaf.

Table 4. Number and percentage of resistant callus regenerated at 4 weeks after subculture on regeneration medium

\begin{tabular}{ccccccc}
\hline \multirow{2}{*}{$\begin{array}{c}\text { Concentration } \\
\text { of SA }\end{array}$} & \multicolumn{2}{c}{$\begin{array}{c}\text { Number of live callus on selection } \\
\text { medium }\end{array}$} & \multicolumn{3}{c}{$\begin{array}{c}\text { Number of regenerated calluson selection } \\
\text { medium (\%) }\end{array}$} \\
\cline { 2 - 7 } & $0 \mathrm{ppm}$ & $15 \mathrm{ppm}$ & $30 \mathrm{ppm}$ & $0 \mathrm{ppm}$ & $15 \mathrm{ppm}$ & $30 \mathrm{ppm}$ \\
\hline $0 \mathrm{ppm}$ & 10 & 1 & 3 & 10.00 & 0.00 & 33.33 \\
$15 \mathrm{ppm}$ & 9 & 3 & 0 & 33.33 & 66.67 & 0.00 \\
$20 \mathrm{ppm}$ & 3 & 10 & 3 & 66.67 & 20.00 & 66.67 \\
$25 \mathrm{ppm}$ & - & 8 & 3 & - & 25.00 & 33.33 \\
\hline
\end{tabular}

concentrations of fusaric acid. The results showed that the treatment of salicylic acid in vitro had no significant effect on the incubation period and the percentage of disease symptoms. The initial symptoms of callus without salicylic acid treatment appeared 16 days after inoculation, whereas in the treatment of salicylic acid at all concentrations were a day appear faster than the control treatment (Table 2). Salicylic acid as an inducer compounds had not yet suppressed the time of appearance of disease symptom in in vitro shallot callus culture.

Fusaric acid at a concentration of $15 \mathrm{ppm}$ could inhibit the growth and even caused death of callus. Death rates of control callus reached $93.33 \%$, but the callus death rates in salicylic acid treatment was relatively lower than in the control, ranged from $47.38 \%$ to $87.5 \%$. Screening in vitro was also performed in the same medium by increasing the concentration of fusaric acid by a level higher than the initial concentration (30 ppm). The results showed that callus survival rates decreased, as indicated by the high death rates of the callus, both in the control and salicylic acid treatments. Tested resistance by fusaric acid at a concentration of $30 \mathrm{ppm}$ which was caused the death of control callus reached an average of $83 \%$ (Table 3 ). So we demonstrated that the concentration was the concentration which caused mortality up to 50\%. Damayanti (2002) reported that fusaric acid at concentration of $30-45 \mathrm{ppm}$ was the lethal concentration / LC50 in screening in vitro of fusarium wilt in banana shoots 'Abaka'. Likewise, Sujatmiko (2013) reported that fusaric acid at a concentration of $30-60 \mathrm{ppm}$ was the optimum concentration in resistance screening to fusarium wilt in melon callus in vitro.

The results suggested that callus without salicylic acid treatment had a relatively low resistance level. The percentage of callus deaths in control treatment (no treatment salicylic acid) reached $83.33 \%$. But after being induced by salicylic acid at concentration of $20 \mathrm{ppm}$, callus showed better resistance level. The salicylic acid treatment at concentration $15 \mathrm{ppm}$ and 25 ppm had low resistance levels, shown by the percentage of callus death which reached $100 \%$ and $80 \%$, respectively (Table 3). Treatment of salicylic acid at a concentration of $20 \mathrm{ppm}$ decreased callus death by $16.66 \%$ in selection medium containing $30 \mathrm{ppm}$ of fusaric acid. Suspected of salicylic acid at a concentration $20 \mathrm{ppm}$ might be able to suppress the effect of fusaric acid. Salicylic 
acid compound as the inducer agent of defense could increase the synthesis of peroxide (PO) and polyphenol oxidase (PPO) enzymes. Both of these enzymes associated with the induction of plant resistance against pathogens and some plant defense mechanisms, such as biosynthesis of lignin and other oxidative phenol (Bestwick et al., 1998; Abo-Elyousr et al., 2009; Dihazi et al., 2011).

Fusaric acid was a compound produced by the genus Fusarium oxysporum which were toxic at a certain concentration. Fusaric acid could hydrolyse the protein constituent of plant cell walls and damaged plants metabolism, causing a loss in water and mineral salts in the plant cells as a result of a disruption in cell permiabelitas (Gauman 1957). This was which caused shallot callus to shrink and die. As already been described above, salicylic acid had a role in lignification process. Lignification strengthen the cell walls of callus (Dihazi et al., 2011), so that fusaric acid compounds could not hydrolise the callus's cell walls. Thus, the metabolism of the cells was not disturbed and the callus could grow well.

Resistance level of shallot callus increased from a very susceptible to susceptible with salicylic acid treatment $(20 \mathrm{ppm})$. Based on the disease intensity value, the criteria of plant resistance could be classified into four group, i.e. resistant (IP $=1 \%-20 \%)$, moderate $(\mathrm{IP}=21 \%-40 \%)$, susceptible $(\mathrm{IP}=41 \%-70 \%)$, and very susceptible (IP $=71 \%-100 \%)$ (Yunita and Sudarsono, 2004). Thus based on the result, induced resistance by salicylic acid at a concentration of $20 \mathrm{ppm}$ was the optimum concentration in reducing toxic symptoms.

A group of callus which showed no toxic symptoms of fusarium and could grow after inoculation was called resistant callus. Resistant callus was subcultured for recovery and multiplication process. It was intended that the callus could run metabolism process normally and to reduce the death rate for too long in the medium. Callus able to regenerate was characterised by the change in colour, texture, and form of the callus. Regeneration was preceded by the change in callus colour from yellowish white to greenish. Callus growing form globular cluster (organised) evolved into cotyledons. The results of visual observations showed that callus regenerated by forming buds and roots. The results of visual observations could be seen in Figure 4.

The number of resistant callus which were successfully regenerated was shown in Table 4. Based on Table 4 , it could be explained that the result of resistance induced callus had a better regeneration ability compared with callus from control treatment. Before being inoculated, the regeneration ability of SA induced callus at a concentration of $20 \mathrm{ppm}$ was the highest $(66.67 \%)$, followed by the treatment of $15 \mathrm{ppm}$ salicylic acid $(33.33 \%)$. But at $25 \mathrm{ppm}$ concentration treatment, the callus was dead caused by contamination. Meanwhile, the regenerated control callus was only $10 \%$. Furthermore after inoculation, SA induced callus at concentration of $20 \mathrm{ppm}$ was able to regenerate more responsive, up to $66.67 \%$. Meanwhile, the regeneration ability of callus in SA treatment at concentration of $25 \mathrm{ppm}$ was relatively similar to control treatment, i.e. $33.33 \%$.

Regeneration ability was the callus ability to grow and develop into organs of plant. Before the inoculation, callus without salicylic acid treatment had low regeneration ability. Once treated with SA, its regeneration ability was increased (Table 4). Callus treated with salicylic acid at a concentration of 20 ppm and inoculated had adequate ability to regenerate better than those without SA treatment. Salicylic acid compounds, in addition to induce callus resistance to fusarium disease, could also induce the growth and development of the onion callus in vitro. According to Vicente and Plansencia (2011), salicylic acid compound could regulate plant growth by helping the growth and development of plants, such as seed germination, vegetative growth of the plants, as well as physiological processes in plant tissue such as photosynthesis, respiration, and through the mechanism of unknown chemical.

\section{CONCLUSION}

Exogenously applied salicylic acid at concentrations of 10,20 , and $25 \mathrm{ppm}$ in vitro had no significant effect on the incubation period and toxic symptoms of callus of shallot cv 'Bima Brebes', but salicylic acid at concentration of $20 \mathrm{ppm}$ could be recommended to induce the resistance to fusarium wilt disease in onions in vitro. Salicylic acid compound had effect to growth and regeneration of shallot cv.'Bima Brebes' callus.

\section{ACKNOWLEDGEMENT}

The author would like to thank the Dirjen DIKTI on graduate education scholarship program BPPDN-DIKTI (Scholarship for Post-Graduate Internal Affairs Directorate of Higher Education).

\section{REFERENCES}

Abo-Elyousr, K. A. M., M. A. M. Husseiun, A. D. A. Allam, and M. H. Hasan. 2009. Salicylic 
Acid Induced Systemic Resistance on Onion Plants Against Stemphylium vesicarium. Archives of Phytopathology and Plant Protection, 42 (11): 1042-1050.

Agrios, G. N. 2005. Plant Pathology. 5th Ed. San Diego USA: Academic Press, pp. 948.

Arrai, M. and M. Takeuchi. 1993. Influence of Fusarium Wilt Toxin(s) of Carnation Cells. Plant Cell Tissue Org Cult., 34: 287-293.

Badriah, D. S. 2001. Uji Resistensi Kultivar Gladiol Introduksi terhadap Fusarium oxysporum In Vitro dan In Vivo. Tesis. Institut Pertanian Bogor.

Bestwick, C. S., I. R. Brown, and J. W. Mansfield. 1998. Localized Changes in Peroxidase Activity Accompany Hydrogen Peroxide Generation During The Development of A Non Host Hypersensitive Reaction in Lectuce. Plant Physiol, 118: 1067-1078.

Cramer, S. C. 2000. Breeding and Genetics of Fusarium Basal Rot Resistance in Onion. Euphytica, 115: 159-166.

Damayanti, F. 2002. Seleksi In Vitro untuk Ketahanan terhadap Penyakit Layu Fusarium pada Tanaman Abaka (Musa Textilis Nee). Tesis. Institut Pertanian Bogor.

Dihazi, A., M. A. Seghini, F. Jaiti, F. Daayf, A. Driouich, H. Dihazi, and I. El Hadramil. 2011. Structural and Biochemical Changes in Salicylic Acid Treated Date Palm Root Challenged with Fusarium oxysporum f. sp. albedinis. Journal of Patogens: 1-9.

Gauman. 1957. Fucarid Acid as Wilt Toxin. Phytopath, 47: $342-351$.

Fadhilah, S. 2014. Pengembangan Teknik Deteksi Fusarium Patogenik pada Umbi Bibit Bawang Merah (Allium cepa L. var ascalonicum Backer). Tesis. Institut Pertanian Bogor.

Faradilla. 2011. Induksi Ketahanan Pisang terhadap Fusarium oxysporum f.sp cubense dengan Asam Salisilat dan Asam Fusarat dalam Kultur Jaringan. Tesis. Universitas Gadjah Mada..

Hoerussalam, A., A. Purwantoro, dan K. Andhi. 2013. Induksi Ketahanan Jagung terhadap Penyakit Bulai Melalui Seed Treatment dan Pewarisannya pada Generasi F1. Jurnal Ilmu Pertanian, 16 (2): 42 - 59.

Malamy, J. and D. F. Klessig. 1992. Salicylic acid and Plant Disease Resistance. The Plant Journal, 2 (5): 643 - 654.

Mandal, S., N. Mallick and A. Mitra. 2009. Salicylic acid-Induced Resistance to Fusarium oxysporum f. sp. ly copersici in Tomato. Journal Plant Physiology and Biochemistry, 47: 642-649.
Mishra, R. K., R. K. Jaiswal, D. Kumar, P. R. Sabale, and A. Singh. 2014. Management of Mayor Diseases and Insect Pest of Onion and Garlic: A Comprehenship Review. J. Plant Breed of Crops Sci., 6(11): 160-170.

Murashige T., and F. Skoog. 1962. A Revised Medium for Rapid Growth and Bio Assays with Tobacco Tissue Cultures. Physiologia Plantarum. 15: 473-497.

Nurcahyani, E., I. Sumardi, B. Hadisutrisno, dan E. Suharyanto. 2012. Penekanan Perkembangan Penyakit Busuk Batang Vanili (Fusarium oxysporum f.sp. vanillae) Melalui Seleksi Asam Fusarat secara In Vitro. J.HPT Tropika, 12 (1): 12-22.

Ojha, S. and N. Chatterjee. 2012. Induction of Resistance in Tomato Plants Against Fusarium oxysporum f.sp. lycopersici Mediated Through Salicylic Acid and Trichoderma harzianum. Journal of Plant Protection Research, 52 (2): 220225.

Peterson, G. and R. Smith. 1991. Effect of Abscicic acid and Callus Size on Regeneration of American and International Rice Varieties. Plant Cell Rep., 10: 35-38.

Ryals, J. A., U. Neuenschwander, M. Willits, A. Molina, H.Y. Steiner, and M. Hunt. 1996. Systemic Acquired Resistance. Plant Cell, 8: 1809-1819.

Sorentina, M. S. M., Haliani, Muslimin, dan I. N. Suwastika. 2013. Induksi Kalus Bawang Merah (Allium ascalonicum L.) Local Palu pada Medium MS dengan Penambahan 2,4-D (2,4-Asam Dikloropenoksi Asetat) dan Air Kelapa. Online Journal of Natural Science, 2 (2): 55- 63 .

Sujatmiko, B. 2013. Induksi Ketahanan Tanaman Melon (Cucumis melo L.) terhadap Layu Fusarium melalui Irradiasi Sinar Gamma secara In Vitro. Tesis. Universitas Gadjah Mada.

Sujatmiko, B., E. Sulistyaningsih, dan R. H. Murti. 2012. Studi Ketahanan Melon (Cucumis melo 1) terhadap Layu Fusarium secara In-Vitro dan Kaitannya dengan Asam Salisilat. Jurnal Ilmu Pertanian, 15 (2): 1- 18.

Vicente, M. R. S. and J. Plasencia. 2011. Salicylic acid Beyond Defence: Its Role in Plant Growth and Development. Journal of Experimental Botany, 62 (10): 3321 3338 .

Vlot, A. C., D. A. Dempsey and D. F. Klessig. 2009. Salicylic Acid, A Multifaceted Hormone to Combat Disease. Ann. Rev. Phytopathol, 47: 177-206. 
Wiyatiningsih, S. 2002. Etiologi Penyakit Moler pada Bawang Merah. Tesis. Universitas Gadjah Mada.

Wiyatiningsih S. 2010. Pengelolaan Epidemik Penyakit Moler pada Bawang Merah. Yogyakarta: UPN Press, pp. 106.

Yunita dan Sudarsono. 2004. Metode Inokulasi dan Reaksi Ketahanan 30 Genotipe Kacang Tanah terhadap Penyakit Busuk Batang Sclerotium. Hayati, 11: 53-58. 